\title{
Sintesis dan Uji Aktivitas Antibakteri Senyawa $N$-Fenil-3,4-Diklorobenzamida (Synthesis and Antibacterial Activity Assay of N-Phenyl-3,4-Dichlorobenzamide)
}

\author{
Vinastika Gita Yualanda, Indah Purnama Sary, Dian Agung Pangaribowo \\ Fakultas Farmasi Universitas Jember \\ JIn. Kalimantan No.37, Jember 68121 \\ e-mail korespondensi: indahpurnamasary.farmasi@unej.ac.id
}

\begin{abstract}
In this research, the synthesis of N-phenyl-3,4-diklorobenzamida was carried out by reacting 1,3-diphenylthiourea and 3,4-dichlorobenzoil chloride via bimolecular nucleophilic substitution reaction $\left(S_{N} 2\right)$. The assays for the obtained compound product were purity test (tested by TLC and melting point tester), chemical and physical characterization (shape, color, and solubility), confirmation of the compound and structure (performed by UV-Vis spectrophotometer, FTIR spectrometer, ${ }^{1} \mathrm{H}-\mathrm{NMR}$ and $\left.{ }^{13} \mathrm{C}-N M R\right)$. The result showed that the compound was synthesized successfully with a yield of $42 \%$, then the in vitro test of antibacterial activity against Staphylococcus aureus ATCC 6538 and Pseudomonas aeruginosa ATCC 27853 was conducted by well diffusion method. The compound N-phenyl-3,4-dichlorobenzamida did not have antibacterial activity which showed by the absence of inhibition diameter.
\end{abstract}

Keywords: 1,3-diphenylthiourea, N-phenyl-3,4-dichlorobenzamide, nucleophilic substitution, antibacterial.

\begin{abstract}
Abstrak
Pada penelitian ini dilakukan sintesis $\mathrm{N}$-fenil-3,4-diklorobenzamida dengan mereaksikan 1,3-difeniltiourea dan 3,4-diklorobenzoil klorida melalui reaksi substitusi nukleofilik bimolekuler $\left(\mathrm{S}_{\mathrm{N}} 2\right)$. Senyawa produk yang didapat kemudian diuji kemurnian (pengujian dengan KLT dan titik lebur), karakterisasi sifat fisika kimia (bentuk, warna, dan kelarutan), konfirmasi struktur dengan spektrofotometer UV-Vis, spektrometer FTIR, ${ }^{1} \mathrm{H}-\mathrm{NMR}$ dan ${ }^{13} \mathrm{C}$-NMR. Hasil penelitian menunjukkan bahwa senyawa berhasil disintesis dengan rendemen $42 \%$, kemudian dilakukan uji aktivitas antibakteri secara in vitro terhadap bakteri Staphylococcus aureus ATCC 6538 dan Pseudomonas aeruginosa ATCC 27853 dengan metode sumuran. Senyawa $\mathrm{N}$-fenil-3,4-diklorobenzamida tidak memiliki aktivitas antibakteri yang ditunjukkan dengan tidak adanya diameter hambat.
\end{abstract}

Kata kunci: 1,3-difeniltiourea, $\quad \mathrm{N}$-fenil-3,4-diklorobenzamida, substitusi nukleofilik, antibakteri.

\section{Pendahuluan}

Penyakit infeksi adalah penyakit yang disebabkan oleh virus, bakteri, jamur atau parasit yang mampu menyebabkan resistensi terhadap senyawa antimikroba. Resistensi antimikroba merupakan masalah kesehatan yang serius bagi masyarakat global [1].
Antibiotik merupakan obat pilihan utama dalam mengatasi penyakit infeksi terutama yang diakibatkan oleh bakteri [2]

Resistensi antimikroba dianggap sebagai ancaman kesehatan global maka diperlukan pengembangan dan penemuan obat baru. Pengembangan dan penemuan obat baru dapat 
dilakukan dengan berbagai strategi antara lain turunan obat, penemuan agen antimikroba, obat antivirus, nanopartikel, enzibiotik, ekologi atau pendekatan biologi evolusioner [3]. Salah satu senyawa antibakteri yang poten untuk bakteri gram positif dan bakteri gram negatif adalah $\mathrm{N}$ fenilbenzamida [4]. Senyawa 4-nitro- $N$ fenilbenzamida yang merupakan salah satu turunan $\mathrm{N}$-fenilbenzamida telah teruji memiliki aktivitas sebagai agen antibakteri dan antifungi [5].

$\mathrm{N}$-fenilbenzamida telah disintesis dengan rute interkonversi dari turunan asam karboksilat, pembentukan amida dari aril halida yang dikatalisis logam, oksidasi aldehid, aminokarbonilasi maupun rute lainnya. Rute baru yang digunakan dalam sintesis $N$ fenilbenzamida adalah dengan substitusi nukleofilik antara 1,3-difeniltiourea dan benzoil klorida. Sintesis dengan rute baru tersebut menghasilkan produk murni dengan jumlah rendemen yang tinggi dan menghasilkan produk tunggal [6].

Penelitian ini diawali dengan sintesis turunan $N$-fenilbenzamida yaitu senyawa $N$-fenil3,4-diklorobenzamida. Sintesis dilakukan dengan mereaksikan 1,3-difeniltiourea dan 3,4diklorobenzoil klorida. Senyawa hasil sintesis diuji kemurniannya menggunakan metode Kromatografi Lapis Tipis (KLT) dengan beberapa fase gerak yang berbeda polaritasnya dan dilakukan penentuan titik lebur. Sedangkan senyawa dan struktur hasil sintesis dikonfirmasi dengan menggunakan spektrofotometer UV-Vis, spektroskopi inframerah, ${ }^{1} \mathrm{H}-\mathrm{NMR}$ dan ${ }^{13} \mathrm{C}$ NMR. Senyawa hasil sintesis kemudian diuji aktivitas antibakteri terhadap bakteri gram positif (Staphylococcus aureus) dan gram negatif (Pseudomonas aeruginosa) menggunakan metode sumuran dengan beberapa konsentrasi uji dengan kontrol positif siprofloksasin dan kontrol negatif DMSO.

\section{Metode Penelitian}

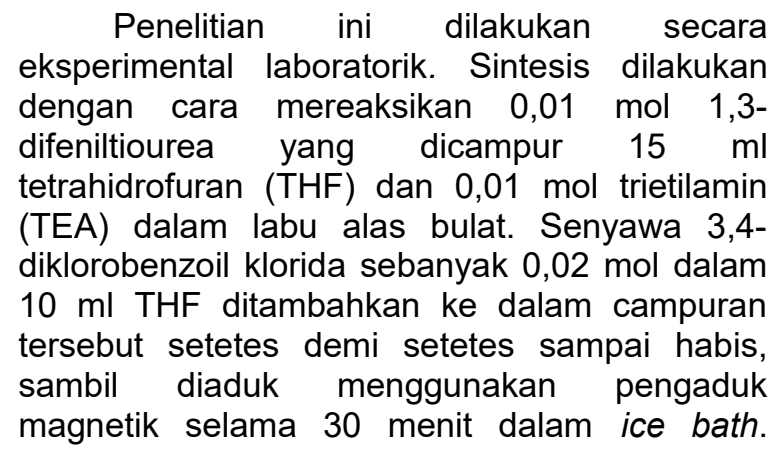

Campuran tersebut kemudian direfluks di atas penangas air, diuji dengan KLT setiap jam sampai terbentuk noda tunggal, apabila masih terdapat noda 1,3-difeniltiourea maka reaksi belum sempurna. Reaksi yang telah selesai dicuci dengan campuran sodium bikarbonat jenuh dan $100 \mathrm{ml}$ air sebanyak tiga kali, kemudian disaring dengan corong buchner.

Proses rekristalisai dilakukan dengan menggunakan etanol panas. Residu pada kertas saring dipindahkan ke dalam gelas beaker, kemudian ditambah etanol secukupnya dan diletakkan di atas penangas air dengan pengaduk magnetik suhu diatur $70-80{ }^{\circ} \mathrm{C}$ dan diaduk perlahan. Pelarut ditambahkan sedikit demi sedikit sampai tepat larut. Larutan kemudian disaring dalam keadaan panas, filtrat ditampung pada gelas beaker yang diletakkan dalam ice bath. Kristal yang terbentuk disaring dengan corong buchner, dicuci dengan etanol sebanyak dua kali. Kristal dipindahkan ke dalam cawan petri yang telah diketahui beratnya, dikeringkan dalam oven pada suhu $50^{\circ} \mathrm{C}$ hingga beratnya tetap, selanjutnya ditimbang untuk mengetahui rendemen hasil sintesis [6].

Optimasi waktu reaksi dilakukan dengan menotolkan produk pada jam ke 1, 2, 3, 4, dan 5 di lempeng KLT dengan pembanding bahan awal yang gunakan yaitu 1,3-difeniltiourea. Totolan pada lempeng KLT dieluasi pada beberapa fase gerak yang berbeda polaritasnya dan diamati bercak noda yang dihasilkan dibawah sinar UV serta hitung nilai Rf masingmasing totolan. Eluen yang digunakan yaitu nheksan:kloroform (1:2).

Uji kemurnian senyawa hasil produk dilihat dengan menggunakan KLT dan titik lebur. Uji kemurnain dengan KLT dilakukan dengan menotolkan senyawa produk pada lempeng KLT dan dieluasi dengan menggunakan tiga sistem eluen yaitu $n$-heksan : kloroform (1:2) sebagai eluen 1, n-heksan: kloroform : etil asetat (4:2:1) sebagai eluen 2 dan n-heksan : kloroform : aseton (4:1:1) sebagai eluen 3 [6]. Lempeng dikeringkan dan noda diamati dibawah sinar UV. Pengujian titik lebur dilakukan dengan menggunakan alat electrothermal melting point apparatus Stuart SMP 10 dan diamati jarak leburnya.

Karakterisasi senyawa produk dilakukan dengan melihat organoleptis dan kelarutan. Uji organoleptis dilakukan dengan melihat bentuk dan warna senyawa produk, Uji kelarutan dilakukan dengan melarutkan senyawa produk dengan berbagai pelarut dan mengelompokkan ke kategori tertentu. 
Penentuan senyawa hasil sintesis dengan spektrofotometer UV dilakukan dengan melarutkan senyawa produk dalam aseton dan dibuat spektrum kurva absorbansi terhadap panjang gelombang pada 200-400 nm. Konfirmasi struktur dengan FTIR dilakukan dengan meletakkan senyawa produk pada pellet dan diamati pada bilangan gelombang 4000-400 $\mathrm{cm}^{-1}$. Konfirmasi struktur dengan ${ }^{1} \mathrm{H}-\mathrm{NMR}$ dan ${ }^{13} \mathrm{C}-\mathrm{NMR}$ menggunakan pelarut aseton- $d_{6}$ dengan standar internal tetrametilsilan (TMS).

Pengujian aktivitas antibakteri dilakukan di dalam laminar air flow (LAF) dengan menggunakan metode difusi sumuran. Permukaan media MHA diolesi suspensi bakteri S. aureus ATCC 6538 dan gram negatif $P$. aeruginosa ATCC 27853 dengan menggunakan lidi kapas steril sampai rata. Sumuran dibuat dengan menggunakan cork borer steril yang berdiameter $10 \mathrm{~mm}$. Larutan uji beberapa konsentrasi senyawa $N$-fenil-3,4diklorobenzamida, larutan uji kontrol negatif dan larutan uji kontrol positif dimasukkan ke dalam sumuran sebanyak $50 \mu \mathrm{l}$ lalu biarkan selama 10 menit agar terjadi difusi, kemudian diinkubasi selama 24 jam pada suhu $37^{\circ} \mathrm{C}$. Pengamatan dilihat dengan melihat besarnya diameter hambat masing masing senyawa yang diuji.

\section{Hasil Penelitian}

Senyawa produk dengan waktu refluks 4 jam menghasilkan noda yang tunggal yang menunjukkan bahwa bahan awal telah habis bereaksi dan reaksi telah berlangsung sempurna. Uji kemurnian senyawa produk berdasarkan KLT pada sistem 3 eluen dengan kepolaran yang berbeda mampu menghasilkan noda tunggal dengan nilai $\mathrm{Rf}$ yang berbeda. Senyawa produk memiliki titik lebur rata rata $177-179{ }^{\circ} \mathrm{C}$ dengan jarak lebur $2{ }^{\circ} \mathrm{C}$.

Karakterisasi senyawa produk dilakukan dengan melihat organoleptis senyawa dan dari data kelarutan. Senyawa produk memiliki bentuk kristal berwarna putih. Berdasarkan uji kelarutan senyawa $\mathrm{N}$-fenil-3,4-diklorobenzamida praktis tidak larut dalam aquadest; sukar larut dalam kloroform p.a, metanol p.a, etanol p.a, nheksan p.a; agak sukar larut dalam DMSO p.a, etil asetat p.a dan aseton p.a.

Penentuan senyawa dengan spektrofotometer UV digunakan untuk melihat panjang gelombang maksimum $\left(\lambda_{\max }\right)$ dan pergeseran panjang gelombang. Bahan awal (1,3-difenitiourea) memiliki $\lambda_{\max } 331,8 \mathrm{~nm}$.
Senyawa produk $N$-fenil-3,4-diklorobenzamida menunjukkan $\lambda_{\max } \quad 330,6 \quad \mathrm{~nm}$. Panjang gelombang senyawa asal jika dibandingkan dengan bahan awal menunjukkan pergeseran hipsokromik. Pergeseran hipsokromik adalah pergeseran ke energi yang lebih tinggi atau menuju panjang gelombang yang lebih kecil [5]. Pergeseran ini dipengaruhi oleh gugus kromofor $(\mathrm{C}=\mathrm{S}$ dan $\mathrm{C}=\mathrm{O})$ dan gugus ausokrom $(\mathrm{NH}-\mathrm{R}$ dan $\mathrm{Cl}$ ).

Hasil analisis FTIR menunjukkan terbentuknya gugus amida. Pita gugus-gugus fungsi yang terdapat pada senyawa target yang ditunjukkan pada Gambar 1. Pita gugus-gugus fungsi yang muncul sesuai dengan literatur [7], yang ditunjukkan pada Tabel 1.

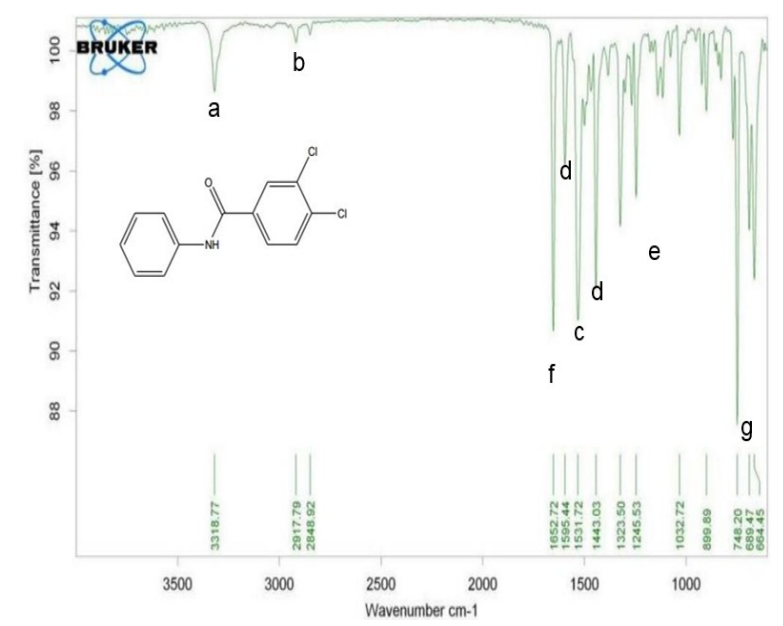

Gambar 1. Spektra inframerah senyawa produk

Tabel 1. Interpretasi serapan IR senyawa produk

\begin{tabular}{clcc}
\hline \multirow{2}{*}{ Gugus } & Tipe vibrasi & \multicolumn{2}{c}{ Frekuensi $\left(\mathrm{cm}^{-1}\right)$} \\
\cline { 3 - 4 } & & Menurut [7] & Percobaan \\
\hline a & $\begin{array}{l}\text { N-H amina } \\
\text { sekunder } \\
\text { (stretch) }\end{array}$ & $3500-3100$ & 3207 \\
b & $\begin{array}{l}\text { Csp }{ }^{2} \text {-H } \\
\text { aromatis } \\
\text { (stretch) }\end{array}$ & $3150-3050$ & 3036 \\
c & $\begin{array}{l}\text { N-H amina } \\
\text { (bend) }\end{array}$ & $1640-1550$ & 1541 \\
d & $\begin{array}{l}\text { C=C aromatis } \\
\text { e }\end{array}$ & 1600 dan & 1616 dan \\
C-N amina & 1475 & 1494 \\
& C-N & $1350-1000$ & $1344-1023$ \\
\hline
\end{tabular}

Spektra ${ }^{1} \mathrm{H}-\mathrm{NMR}$ dapat dilihat pada Gambar 2 dan spektra ${ }^{13} \mathrm{C}-\mathrm{NMR}$ dapat dilihat pada Gambar 3. Perbandingan karakteristik spektra senyawa produk dengan prediksi dari software ChemDraw Ultra 8.0 versi trial dan 
literatur [6] dapat dilihat pada Tabel 2 dan untuk dan ${ }^{13} \mathrm{C}$-NMR ditunjukkan pada Tabel 3.

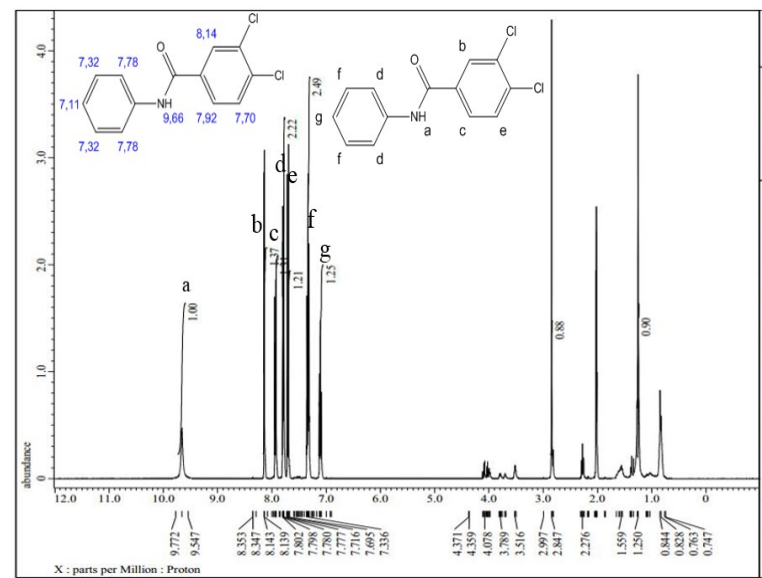

Gambar 2. Spektra ${ }^{1} \mathrm{H}-\mathrm{NMR}$ senyawa produk

Tabel 2. Perbandingan karakteristik spektra ${ }^{1} \mathrm{H}-\mathrm{NMR}$

\begin{tabular}{ccccc}
\hline $\begin{array}{c}\text { Proton } \\
\text { dari } \\
\text { gugus }\end{array}$ & $\begin{array}{c}\text { Hasil } \\
\text { ChemDraw } \\
\text { Ultra } 8.0 \\
(\mathrm{ppm})\end{array}$ & $\begin{array}{c}\delta(\mathrm{ppm}) \\
{[7]}\end{array}$ & Multiplisitas Integrasi \\
\hline a & 8,0 & $5,0-9,0$ & Singlet & 1 \\
b & 7,90 & $7-8,0$ & Singlet & 1 \\
c & 7,77 & $7-8,0$ & Doblet & 1 \\
d & 7,64 & $7-8,0$ & Doblet & 2 \\
e & 7,39 & $7-8,0$ & Doblet & 1 \\
f & 7,24 & $7-8,0$ & Triplet & 2 \\
g & 7,00 & $7-8,0$ & Triplet & 1 \\
\hline
\end{tabular}

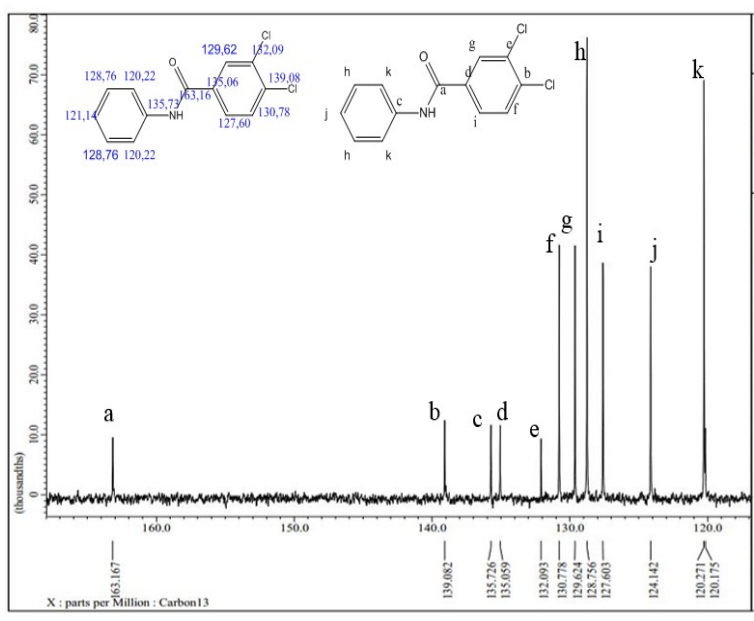

Gambar 3. Spektra ${ }^{13} \mathrm{C}-\mathrm{NMR}$ senyawa produk

Berdasarkan data hasil analisis dengan ${ }^{1} \mathrm{H}-\mathrm{NMR}$, bahwa senyawa hasil sintesis mempunyai 9 atom $\mathrm{H}$ dengan posisi berbedabeda yang ditandai dengan pergeseran kimia $(\delta)$ yang berbeda dan multipisitas yang berbeda pula. Data hasil analisis menunjukkan jumlah atom $\mathrm{H}$ sama dengan jumlah atom $\mathrm{H}$ yang terdapat pada struktur senyawa $N$-fenil-3,4diklorobenzamida, yakni 9 atom $\mathrm{H}$ yang terlihat dari jumlah integrasi. Spektra ${ }^{13} \mathrm{C}-\mathrm{NMR}$ menunjukkan 11 sinyal karbon yang telah sesuai dengan teoritis. Senyawa produk ditunjukkan pada Gambar 4.

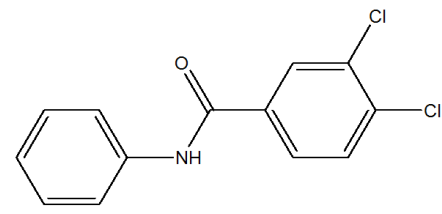

Gambar 4. Senyawa $N$-fenil-3,4-diklorobenzamida

Tabel 3. Perbandingan karakteristik spektra ${ }^{13} \mathrm{C}-\mathrm{NMR}$

\begin{tabular}{ccc}
\hline $\begin{array}{c}\text { Karbon } \\
\text { dari gugus }\end{array}$ & $\begin{array}{c}\text { Hasil ChemDraw } \\
\text { Ultra 8.0 }(\mathrm{ppm})\end{array}$ & $\delta(\mathrm{ppm})[7]$ \\
\hline $\mathrm{a}$ & 164,8 & $155-185$ \\
$\mathrm{~b}$ & 136,8 & $110-175$ \\
$\mathrm{c}$ & 135,9 & $110-175$ \\
$\mathrm{~d}$ & 133,7 & $110-175$ \\
$\mathrm{e}$ & 133,5 & $110-175$ \\
$\mathrm{f}$ & 130,4 & $110-175$ \\
$\mathrm{~g}$ & 129,0 & $110-175$ \\
$\mathrm{~h}$ & 129,0 & $110-175$ \\
$\mathrm{i}$ & 127,0 & $110-175$ \\
$\mathrm{j}$ & 124,4 & $110-175$ \\
$\mathrm{k}$ & 121,6 & $110-175$ \\
\hline
\end{tabular}

Senyawa produk dengan konsentrasi 31,$25 ; 62,5 ; 125 ; 250 ; 500 ; 1.000 ; 2.000 ; 4.000$; 8.000; dan $10.000 \mu \mathrm{g} / \mathrm{ml}$ dan kontrol positif (DMSO) tidak menunjukkan adanya diameter hambat pada $S$. aureus ATCC 6538 dan gram negatif $P$. aeruginosa ATCC 27853, sedangkan pada kontrol positif (siprofoloksasin) dengan konsentrasi $31,25 \mu \mathrm{g} / \mathrm{ml}$ menunjukkan diameter hambat. Diameter hambat rata-rata kontrol positif pada $S$. aureus sebesar $28 \mathrm{~mm}$ dan pada $P$. aeruginosa sebesar $38 \mathrm{~mm}$.

\section{Pembahasan}

Sintesis senyawa N-fenil-3,4diklorobenzamida berhasil dilakukan dengan mereaksikan 1,3-difeniltiourea dan 3,4diklorobenzoil klorida. Sintesis dilakukan dengan cara refluks. Mekanisme reaksi ini berlangsung melalui rekasi substitusi nukleofilik bimolekuler $\left(S_{N} 2\right)$. Reaksi pembentukan senyawa produk 
dapat dilihat pada Gambar 5. Gambar 5 menjelaskan bahwa sterik yang meruah pada 1,3-difeniltiourea memberikan halangan pada 3,4-diklorobenzoil klorida, sehingga hanya satu amina yang berhasil tersubstitusi (i). Penataulangan terjadi karena halangan sterik yang besar yang dimiliki oleh (i), sehingga mengubahnya menjadi senyawa (ii). Ketidak stabilan dari senyawa (ii) mengakibatkan penataulangan menjadi senyawa (iii), yang merupakan tautomer dari amida (iv), dan menghasilkan senyawa (v) disaat yang bersamaan. Senyawa (v) merupakan fenil isotiosianat (produk samping) yang akan hilang dalam fase etanol selama proses rekristalisasi [6].

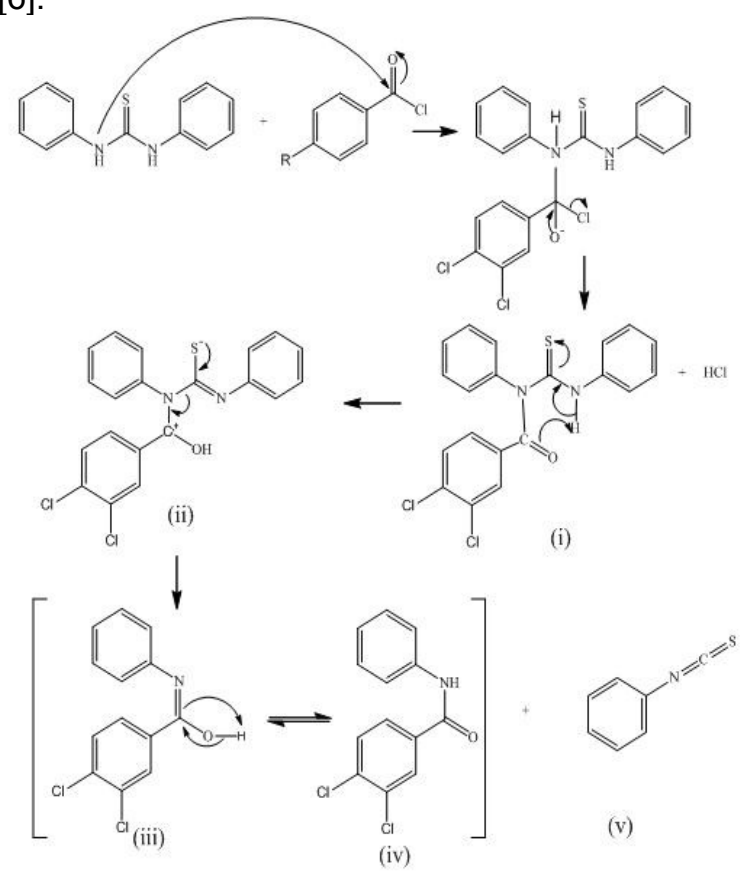

Gambar 5. Mekanisme sintesis senyawa produk

Uji aktivitas antibakteri senyawa produk menunjukkan tidak adanya aktivitas antibakteri. Aktivitas antibakteri tergantung pada struktur molekul senyawa, pelarut yang digunakan dan jenis bakteri [8]. Senyawa kimia memiliki struktur yang spesifik dengan fungsi yang spesifik, misalnya senyawa yang berfungsi sebagai antibakteri. Mekanisme aksi struktur dan gugus molekul spesifik dari suatu senyawa berperan dalam interaksi senyawa dan sasaran [9].

Senyawa produk memiliki struktur yang mengandung $N$-fenilbenzamida. Senyawa 4nitro- $N$-fenilbenzamida memiliki aktivitas antibakteri [4]. Menurut prediksi dari ChemDraw Ultra 8.0 versi trial, nilai ClogP senyawa 4-nitro-
$N$-fenilbenzamida sebesar 2,82; kontrol positif sebesar -1,15; dan senyawa produk memiliki nilai $\mathrm{Clog} P$ 4,23. Nilai ClogP menunjukkan senyawa produk merupakan senyawa non polar.

Senyawa produk memiliki lipofilitas yang lebih besar daripada senyawa yang dilaporkan, maka kemungkinan besar senyawa $\mathrm{N}$-fenil-3,4diklorobenzamida tidak memberikan aktivitas yang disebabkan oleh tingginya lipofilitas dari senyawa untuk menembus sel sehingga tidak dapat berinteraksi dengan sasaran (reseptor bakteri). Metode difusi tidak cocok digunakan pada sampel yang bersifat non polar atau sampel yang tidak mudah berdifusi ke dalam media agar [10]. DMSO yang digunakan sebagai pelarut pada kontrol negatif tidak menunjukkan aktivitas antibakteri, sehingga pelarut DMSO yang digunakan tidak memberikan pengaruh pada uji antibakteri. Oleh karena itu, senyawa produk tidak memberikan aktivitas pada bakteri $S$. aureus dan $P$. aeruginosa.

\section{Simpulan dan Saran}

Senyawa $N$-fenil-3,4-diklorobenzamida memiliki bentuk kristal yang berwarna putih dengan rendemen sebesar $42 \%$. Kelarutan senyawa produk yaitu praktis tidak larut dalam aquadest; sukar larut dalam kloroform p.a, metanol p.a, etanol p.a dan n-heksan p.a; agak sukar larut dalam DMSO p.a, etil asetat p.a dan aseton p.a. Berdasarkan uji kemurnian senyawa produk memiliki titik lebur $177-179{ }^{\circ} \mathrm{C}$ dan pada lempeng KLT memiliki noda tunggal pada tiga eluen dengan kepolaran yang berbeda. Berdasarkan spektra IR, ${ }^{1} \mathrm{H}-\mathrm{NMR}$ dan ${ }^{13} \mathrm{C}-\mathrm{NMR}$ menunjukkan bahwa senyawa produk adalah $N$ fenil-3,4-diklorobenzamida.

Senyawa $N$-fenil-3,4-diklorobenzamida memiliki nilai diameter hambat $0 \mathrm{~mm}$ terhadap bakteri $S$. aureus dan $P$. aeruginosa, sehingga senyawa produk tidak memiliki aktivitas antibakteri. Sehingga perlu dilakukan uji aktivitas antibakteri dengan menggunakan bakteri lain atau metode uji yang lain. Perlu dilakukan uji aktivitas lain selain antibakteri.

\section{Daftar Pustaka}

[1] World Health Organization [internet]. [Geneva]: World Health Organization; 2016 [cited 2016 September 5]. Available from: http://www.who.int/mediacentre/factsheets/f s194/en/. 
[2] Kurniawati AFS, Satyabakti P, Arbianti N. Perbedaan risiko multidrug resistance organisms (MDROs) menurut faktor risiko dan kepatuhan hand hygiene. Jurnal Berkala Epidemiologi. 2015; 3(3): 277- 289.

[3] Roca, Akova M, Baquero F, Carlet J, Cavaleri M, Coenen S, et al. The global threat of antimicrobial resistance: science for intervention. New Microbe and New Infect. 2015; 6: 22-29.

[4] Pasha FA, Muddassar M, Lee C, Cho SJ. Mechanism based QSAR studies of $N$ phenylbenzamides as antimicrobial agents. Environ Toxicol Pharmacol. 2008; 26: 128135.

[5] Khrisna SM, Padmalatha Y, Raindranath LK, Chandrakala $S$. Synthesis characterization and biological evaluation of 4-nitro- $N$ phenylbenzamide and (4-nitrophenyl) (piperidine-1-yl) methanone. Int $\mathrm{J}$ Chem Pharm Sci. 2015; 3(1): 1475-1477.
[6] Sary IP, Siswandono, Budiati T. Nphenylbenzamide synthesis by nucleophilic substitution with 1,3-diphenylthiourea. Int J Pharm Pharm Sci. 2015; 7(3): 481-482.

[7] Pavia DL, Lampman GM, Kriz GS, Vyvyan JR. Introduction to spectroscopy. $4^{\text {th }}$ ed. USA: Cengage Learning Inc. 2009.

[8] Parekh J, Inamdhar P, Nair R, Baluja S, Chanda S. Synthesis and antibacterial activity of some Schiff bases derived from 4aminobenzoic acid. J Serb Chem Soc. 2005; 70(10): 1155-1161.

[9] Ys H. Telaah kesamaan struktur beberapa senyawa antibakteri gram positif dan potensi pembuktiannya. Nat Sci: J Sci Tech. 2015; $4(2)$.

[10] Cos P, Vlietinck AJ, Berghe DV, Maes L. Antiinfective potential of natural product: how to develop a stronger in vitro 'proof-of concept'. J Ethnopharmacol. 2006; 106: 290-302. 